\title{
Behavioural Finance and Investor Protection Regulations
}

\author{
Gerald Spindler
}

Received: 18 November 2010 / Accepted: 7 June 2011 /

Published online: 29 June 2011

C The Author(s) 2011. This article is published with open access at Springerlink.com

\begin{abstract}
The article deals with behavioural assumptions in legal norms, in particular with regard to investor protection norms in Europe and Germany as well as court rulings. Whereas traditional legal norms are based on the assumption of rationale behaviour, the financials crisis has demonstrated the pitfalls of the classical notions of economics, thus leading to new insights of behavioural economics. However, it is still unclear how behavioural economics may serve as a means to improve legal protection of investors. Neither a strong paternalism nor a simple extension of information obligation may suffice in the future.
\end{abstract}

Keywords Financial Crisis · Investment Consulting · Economic Analysis · Clients' Information Overload

The financial crisis had severe implications among all sectors of finance regulation, namely banking supervisory regulations, insolvency (and reorganization) issues, as well as investor protection. The Lehmann Brother's insolvency is just one famous example of the impact which the financial crisis had upon private (retail) investors and which has caused deep troubles for thousands of investors who had bought Lehmann certificates, sometimes even leading to the destruction of their economic existence. Hence, it is no wonder that besides stronger supervisory regulations investor protection is also on the agenda of legal discussions, in particular questioning whether traditional means and instruments are still sufficient in order to avoid similar problems in the future. On the German as well as on the European level, new laws or directives are on the

G. Spindler $(\bowtie)$

Institute of Commercial Law, Faculty of Law, University of Göttingen, Platz der Göttinger Sieben 6, 37073 Göttingen, Germany

e-mail: gspindl@gwdg.de 
agenda in order to protect investors, such as recently the directive on alternative investment funds managers (AIFM) ${ }^{1}$ (Spindler and Tancredi 2011), the second consultation on the "Markets in Financial Instruments Directive (MiFID) II"2 or the revised Prospectus Directive. ${ }^{3}$ On the other hand, an investor protection that would overregulate markets may lead to an inefficient underproduction of new financial products. Striking the exact balance between these two poles is a difficult task for legislators. Hence, normative "red leads" in investor protection are always sought and being used by legislators around the globe, in particular the European and the German legislator. The basic traditional paradigm for legislators (and economists) concerning investor (and consumer) protection always had been rationale behaviour, in particular its underlying assumptions of well-informed market participants; market failures and information asymmetries, thus, have to be overcome by introducing obligations to inform in order to enhance the information basis of investors. However, the financial crisis revealed fundamental problems with regard to this traditional approach in finance and securities markets regulation, putting into question the paradigm of rationale behaviour and information obligations.

The article is dedicated to this potential shift in paradigms of investor protection regulation, from an interdisciplinary perspective which, however, focuses on the implications for legal theory-it does not claim to give an exhaustive overview of the impact of behavioural economics upon investor protection nor a complete analysis of all legal provisions. The article focusses on potential modifications in investor protection stemming from behavioural economics, discussing also their limits.

Hence, we will discuss first shortly what the traditional paradigms stemming from economic theory were in the past, mainly the axiom of rational (II). Then we will turn to the actual legal reflections of these traditional paradigms (III) in German and European legislations, which are strongly based upon information for investors. European legislation always have been concerned with market failure resulting of informational asymmetries, thus it may serve as a (perfect) example of how information obligations had been introduced as a means of investor protection. However, these assumptions of rational have to be confronted with insights of behavioural economics, in particular behavioural finance (IV). From a legal perspective, the obvious issue is how to reconcile these new insights about irrational behaviour with legal regulations based upon traditional paradigms of rationality (V). In addition, we observe also on the level of courts the same approaches, which could be demonstrated in analysing some Lehmann Brother cases with regard to investors claiming damages, based upon infringements of obligations to disclose conflict of interests. However, from a more behavioural economics perspective, these obligations may lead to non-expected results, in particular concerning the "kick-back" payments and duties to disclose these payments (VI). Finally, we will discuss if a strong paternalism should be

\footnotetext{
${ }^{1}$ Directive of Alternative Investment Fund Managers, text agreed in the trilogue on 26 October 2010: http:// register.consilium.europa.eu/pdf/en/10/st15/st15053-re01.en10.pdf (accessed 27 April 2011); for a more detailed discussion of the AIFM-directive, see Spindler and Tancredi (2011)

${ }^{2}$ Communication from the Commission to the European Parliament, the Council, the European Economic and Social Committee, and the Committee of the Regions, reinforcing sanctioning regimes in the financial services sector, 08.12.2010, downloadable at: http://ec.europa.eu/internal_market/consultations/docs/2010/ sanctions/COM_2010_0716_en.pdf (accessed 27 April 2011).

${ }^{3}$ Directives $2010 / 73 / \mathrm{EU}$ of the European Parliament and the Council of 24 November 2010 amending Directives 2003/71/EC on the prospectus to be published when securities are offered to the public or admitted to trading and 2004/109/EC on the harmonisation of transparency requirements in relation to information about issuers whose securities are admitted to trading on a regulated market, OJ EU L 327, p. 1 dated 11.12.2010.
} 
the radical turn for investor protection in contrast to the traditional information obligation approach (VII).

\section{Traditional Paradigms}

The traditional paradigms in economics of securities markets can be described very briefly as based on rational behaviour assumptions. Rational behaviour implies well-defined preferences and accordingly taken decisions. These preferences exactly reflect true costs and benefits, in situations of uncertainty people collect all available information, evaluate it and make decisions according to their preferences (Camerer et al. 2003, pp. 1211, 1214). Investors and market participants take all kind of available information into account, which is then transferred into individual preferences, which lead to trade on markets. Moreover, their expectations and prognostics about market evolutions influence their offers on markets by means of calculating expected income for the future. The probability of an evolution is calculated against the expected income, thus forming an investor-decision basis. Thus, prices on markets reflect the aggregated preferences of market participants and guarantee (weak-) efficiency (Gilson and Kraakman 1984, p. 549; Jensen 1978, p. 95) of the securities markets, prices reflect in theory all available information (Fama 1970, p. 383). Hence, information is one of the basic elements for investor rational decisions.

The "Capital Asset Pricing Model (CAPM)" yields three important views of financial markets: First, that they are efficient, second that asset prices depend not on the variance, but rather on the covariance of the underlying payoffs with a particular, privileged portfolio, and third that all portfolio holders may be perfectly happy to hold only a few specially designated mutual funds (Geanakoplos and Shubik 1990, p. 55). It provides a theoretical structure for the pricing of assets with uncertain returns (Bollerslev et al. 1988, p. 116). Building upon the model of portfolio choice developed by Harry Markowitz (1959) the CAPM assumes investors are risk averse and, when choosing among portfolios, they care only about the mean and variance of their one-period investment return (Fama and French 2004, pp. 25-26). When analysing the risk of an individual security, however, the individual security risk must be considered in relation to other securities in the portfolio. In general, investors are confronted with two types of risks: unsystematic and systematic risks. Unsystematic risk is the component of the portfolio risk that can be eliminated by increasing the portfolio size; systematic risk on the other hand is associated with overall movements in the general market or economy and therefore is often referred to as the "market risk" (Galagedera 2004, p. 2). The market risk is the component of the total risk that cannot be eliminated through portfolio diversification.

However, even neo-classical economics based on the assumption of rational behaviour admits that transaction costs and informational asymmetries may influence market efficiency. One famous example is the "bitter lemon paradigm" by Akerlof (1970, pp. 488-500) showing that informational asymmetries may lead to an inefficient offer of only low quality products in a market when buyers are not able to assess the quality of a product and sellers of high quality products suffer from these asymmetries. Note, however, that these transaction costs and informational asymmetries do not undermine the basic assumption of rational behaviour; in contrary, the problem of informational asymmetry is just the result of a rational calculation of market participants which are not willing to pay high transactions costs in order to inform themselves. Buyers in the Akerlof paradigm are just weighing the benefits and costs of getting more information about a product so that still rational behaviour is at stake. 
Moreover, if market participants behave in an irrational way the market mechanism will eliminate them at least in the long run as irrational strategies are inefficient and lead to unsustainable costs for those market participants. Thus, we have to take into account in the long run learning effects of market participants that will eliminate deviating and irrational behaviour as "learned" market participants are more skilful than others (Camerer 1995, p. 675). In particular, professional intermediaries and market participants should, thus, have a strong incentive to behave in a rational way so that markets are assumed to work efficiently-the circle is closed.

Even in case of informational asymmetries, it is in theory likely that markets (or market participants) will produce new instruments in order to overcome the asymmetry, in particular by "inventing" quality-signalling mechanisms (Spence 1976, pp. 591-597). Such signalling mechanisms may consist in ratings given to financial products or companies in order to signal to the market (and the investor) that these financial products are reliable and of "good quality." Indeed, this is the underlying rational of rating agencies as well as of other institutions that assess financial products and make them sellable (Liu and Thakor 1984, pp. 344-351; Neubäumer 2008, pp. 733-740), avoiding thus the Akerlof symptom. Moreover, reputation mechanisms serve as incentives for these intermediaries to deliver "good services" and to enhance their quality signals so that secondary markets incentives help to overcome the fundamental informational asymmetry of complex products - in theory.

However, the recent past has shown that those reputation mechanisms obviously may turn out to be defective. Since the financial crisis the reputation of rating agencies declined constantly as inter alia they were made responsible for the breakdown of financial markets. But what caused this decrease in credibility? Rating agencies find themselves in a permanent conflict of interests: On the one hand there is the call for an objective and realistic estimation, but on the other hand it is not negligible that the agencies are mandated and, in consequence, paid by the issuer. Therefore they try to act in a way the issuer can take advantage of. A negative assessment or a downgrading usually leads to contrary effects, since a downgrade could even trigger certain covenants or other conditional obligations (Covitz and Harrison 2003, p. 6). Moreover, rating agencies tried to enter into markets whose mechanisms were largely unknown to them - thus, traditional reputation mechanisms did not work as the wish to expand into new markets prevailed prudence (Goodhart 2008, pp. 337-339).

\section{Legal Reflections of Traditional Paradigms: Information Duties}

These basic assumptions of rational behaviour of market participants and of the instruments to overcome informational asymmetry are deeply rooted in legal regulations. In addition, as legal regulations are mostly seen by economists as a means to correct (and overcome) market failures it goes without saying that legal framework protecting investors concentrates on information disclosure in general (besides other norms like avoiding conflicts of interests etc.) - due to the Akerlof paradigm of informational asymmetries. The European (and thus the German) legislation is a good example for this approach as it concentrates on enhancing the information basis for investors:

While professional market participants such as banks or other financial intermediaries are skilled in assessing decisive economic data in order to judge the outcome of financial products, the private investor often is not well grounded in the relevant information. In contrast to the acquirer of a real touchable asset the investor cannot physically check the 
condition of the object and therefore can hardly estimate the actual and future value. Moreover, it takes too much time for a retail client to look intensively for information available on markets concerning financial products - even more as they vary quite a lot and their legal constructions cannot easily be understood. Hence, it does not surprise that European and national legislations lay the accent on handing over the client (the investors)

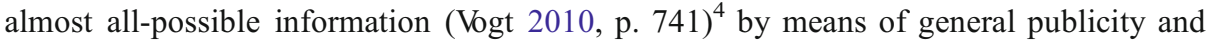
transparency, or by means of mandatory individual consultation of the client by the bank (or other financial intermediaries). A short overview (Cherednychenko 2010, pp. 403424; Grundmann 2005, p. 482; 2008, p. 45; 2010, p. 467; Moloney 2008) of European and German regulations of norm that obliges intermediaries to inform clients will quickly prove this finding (Ben-Shahar and Schneider 2010):

\section{Markets in Financial Instruments Directive}

The most important European directive (amongst more than other 20 directives) takes this approach, the MiFID $^{5}$ (Critical acclaim in this context Hopt 2009, p. 1873; Merkt 2010, pp. 2207, 2221). Thereby the European legislator obliges investment firms to provide clients or even potential clients with appropriate information about the investment firm itself and its services, about financial instruments and proposed investment strategies, including appropriate guidance on and warnings of the risks associated with investments in those instruments or in respect of particular investment strategies, about execution venues and about costs and associated charges, Art. 19 (3) MiFID. These duties are explicitly aimed at providing clients an insight view into the nature and risks of the investment service and of the specific type of financial instrument that is being offered. Thus, clients shall be provided with a fully informed basis to take investment decisions. Offering this information the investment firm may use a standardized format.

Core of the regulation is the so-called "client classification" (Art. 4 (10f.), Art. 19 (10c), Art. 21 (6) MiFID. The directive establishes three client categories, which are decisive for the extent of information obligations: The professional client, the eligible counterparty and the retail clients.

Professional clients are those labelled who dispose of sufficient experiences, knowledge and adequate expertise to make investment decisions and to be able to judge the risks linked with it (Art. 4 (11), Annex II MiFID). Embraced by the term are in any case all corporate bodies that are listed or must be supervised by the state to act in the finance market, such as investment firms, financial institutions or funds. Moreover, "big" companies with a total asset of 20 million are considered as professionals (Annex II; I (2), MiFID). The classification as "eligible counterparty" represents a sub-category of the class of "professionals" (Art. 24 MiFID). The European legislator, however, accepts that professional clients may opt for the status of "retail client" in order to identify for themselves the information necessary for an informed decision. Therefore, the investment firm itself, acting towards a professional client, is required to provide a less detailed information level. Finally the directive addresses retail clients (Art. 4 (12) MiFID). Any investor that cannot be classified according to the first and second category generally is being considered as a retail investor and benefits from the highest investor's

\footnotetext{
${ }^{4}$ Pointing at Judgements of the European Court of Justice like ECJ, Case C-221/00, [2003] ECR I 10071064; ECJ, Case C-329/02 P, [2004] ECR I 8317-8354; Federal Court of Justice (BGH) 2008, judgement of 04.10.2007-ref. no. I ZR 143/04, Neue Juristische Wochenschrift, p. 1384.

${ }^{5}$ Directive 2004/39/EC of the European Parliament and of the Council of 21 April 2004 on markets in financial instruments amending Council Directives 85/611/EEC and 93/6/EEC and Directive 2000/12/EC of the European Parliament and of the Council and repealing Council Directive 93/22/EEC, OJ EU L 145, p. 1, dated 30.04.2004.
} 
protection. However, under certain conditions a retail client may switch to the first and second category and vice versa (opting up/opting down) (Annex II, Sec I. (4), Sec II, MiFID).

According to the European paradigm, the German Wertpapierhandelsgesetz (Securities Trading Act) classifies clients also by differentiating between professional clients, retail clients and eligible counterparties (Clouth and Lang 2007, recital 48; Duve and Keller 2006, pp. 2425, 2428; Seyfried 2006, pp. 1375, 1377). Every client is to be classified on the evaluation of his own information and consulting requirements (Clouth and Lang 2007, recital 54; Ellenberger and Schaefer 2006, p. 64; Lang 2003, p. 38). ${ }^{6}$ According to $\S 31$ section 1 number $1 \mathrm{WpHG}$ (Securities Trading Act), all services have provide experience, accuracy, and diligence in the interest of the client. An investment service firm is obliged to collect information about the client's knowledge and experience with transactions of certain financial instruments or investment services (know-your-customer principle), the client's investment objective and the client's financial circumstances (Steuer 1999, pp. 793, 801; Weichert and Wenninger 2007, pp. 627, 630; Hannöver 2007, § 110 recital 17). ${ }^{7}$ These duties of exploring the capacities and abilities of a client are crucial for all information and advisement requirements. Hence, $\S 31$ Section $4 \mathrm{WpHG}$ (Securities Trading Act) retains the so-called appropriateness review (Schwintowski 2009, § 18 recital 2 ff.). ${ }^{8}$

\section{Directive on Insurance Mediation}

Whereas the MiFID covers the regulation of investment firms, insurance intermediaries on the European level are being dealt with by the Directive on Insurance Mediation stating that any insurance intermediary shall provide the customer with a range of defined information prior to the conclusion of any initial insurance contract (art. 12 (1) DIM). ${ }^{9}$ These information duties involve general data on the identity, address, registration, and capital participation of the intermediary in the insurance undertaking, which offers the product of interest. Furthermore, to give the client a true and well-founded basis for decision, the intermediary shall disclose whether he is under a contractual obligation to conduct insurance mediation business exclusively with one or more insurance undertakings or not. According to the information conditions, the directive obliges the intermediaries to provide the information required on paper or any other durable medium, in a clear and accurate manner, comprehensible to the customer and in an official language of the Member State of the commitment or in any other language agreed by the parties (art. 13 DIM).

\section{Case Law to Inform Properly According to German Courts}

Besides the implementation of the cited European legislation in the "Wertpapierhandelsgesetz," German courts have developed a bulk of case law based on the figure of precontractual relationship (culpa in contrahendo) as well as on the idea of tacitly concluded contract on consultation when a bank sells financial products to the investor. As the starting point of a wide jurisprudence one can consider the so-called "Bond" Judgement. Here the German Federal High

\footnotetext{
${ }^{6}$ Cf. Report of the Financial Commitee of the Bundestag on the Bill (Government draft) 2. Finanzmarktförderungsgesetz, Bundestagsdrucksache (BT-Drucks.) 12/6679, p. 104.

${ }^{7}$ Federal Court of Justice (BGH) (1993), judgement of 06.07.1993-ref. no. XI ZR 12/93, Wertpapiermitteilungen, p. 1455.

${ }^{8}$ The information requirements of $\S 31$ para. 3 and 4 WpHG (Securities Trading Act) correspond therefore mainly with $\S \S 5$ ff. VVG, VVG-Info-VO 18.12.2007 (BGBI. I Nr. 66, 21.12.2007), p. 3007.

${ }^{9}$ Directive 2002/92(EC of the European Parliament and of the Council of 9 December 2002 on insurance mediation, OJ EU L 009, p. 3, dated 15.01.2003.
} 
Court made clear that in general every banking institution has to find out about the client's investment target, his readiness to assume risks, and his expert knowledge before selling him a financial product. ${ }^{10}$ Since then the court more and more has refined the requirements concerning the client's clarification, ${ }^{11}$ such as the duty to provide an advisory service adequate as well for the client as for the investment offered. ${ }^{12}$ Hence (and independently of the written legal requirements), courts required intermediaries to analyse the client's knowledge about investment decisions in general and about the aspired investment in particular. Afterwards, the client's readiness to assume risks shall be discovered to finally find out, whether the investment offered fits the client's requirements. Concerning the investment firm needs to inform the client completely and correctly about all circumstances being essential to the investment, ${ }^{13}$ such as general risks regarding the economic situation and those risks particularly linked to the investment, such as interest and currency risks (Grüneberg and Sutschet 2007, § 311 recital 99). Moreover the financial institution also has to disclose so-called "kick-backs" (exchange commissions paid to a third party who is "producer" of the financial product) in order to reveal potential conflict of interests (Spindler 2009, p. 1821). ${ }^{14}$

\section{Behavioural Economics and Investor Protection}

As indicated, the financial crisis forces us to reconsider the traditional paradigms of rational of market participants. Obviously, even professionals of financial intermediaries suffered from irrationalities and psychological effects thus aggravating other factors of the crisis. Moreover, more and more the general approach of EU regulation on investor protection is being attacked on grounds of behavioural economics that take irrational behaviour into account (Hirshleifer 2001, p. 1533), ${ }^{15}$ in particular some general effects which could be distilled out of experiments:

Investors

\section{Information Overload}

The first phenomenon, which is, however, not really related to behavioural economics, is the information overload occurred by investors (sometimes also known as the "curse of

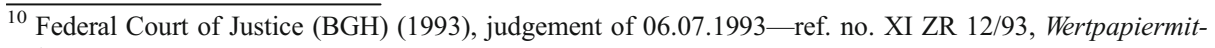
teilungen, p. 1455.

${ }^{11}$ See inter alia Federal Court of Justice (BGH) (2004), judgement of 28.09.2004 - ref. no. XI ZR 259/03, Wertpapiermitteilungen, p. 2205; Federal Court of Justice (BGH) (2001), judgement of 08.05.2011 - ref. no. XI ZR 192/00, Wertpapiermittelungen, p. 1758; Federal Court of Justice (BGH) (1999), judgement of 05.10.1999-ref. no. XI ZR 296/98, Wertpapiermitteilungen, p. 2300; Federal Court of Justice (BGH) (1997), judgement of 24.09.1996 - ref. no. XI ZR 244/95, Wertpapiermitteilungen, pp. 309, 311; Federal Court of Justice (BGH) (1993), judgement of 06.07.1993 - ref. no. XI ZR 12/93, Wertpapiermitteilungen, p. 1455.

${ }^{12}$ Federal Court of Justice (BGH) (1993), judgement of 06.07.1993-ref. no. XI ZR 12/93, Neue Juristische Wochenschrift, p. 2433.

${ }^{13}$ Federal Court of Justice (BGH) (2005), judgement of 21.03.2005-ref. no. II ZR 310/03, Neue Juristische Wochenschrift, p. 1784.

${ }^{14}$ Federal Court of Justice (BGH) (2009), judgement of 12.05.2009-ref. no. XI ZR 586/07, Wertpapiermitteilungen, p. 1274; Federal Court of Justice (BGH) (2007), judgement of 19.12.2006-ref. no. XI ZR 56/05, Wertpapiermitteilungen, p. 487.

${ }^{15}$ See in general the overview of experiments and theories De Meza et al., Financial Capability: A al Economics Perspective, 2008, downloadable at: http://www.fsa.gov.uk/pubs/consumer-research/crpr69.pdf (accessed 27 April 2011).
} 
knowledge," cf. Camerer et al. 1989, p. 1232). Whereas the motives of legislators to inform investors more and better are benevolent, in practice investors cannot really assess the quality and amount of information, which is given to them. Extreme examples like flicking through more than 60 pages when an insurance shall be bought on the Internet may give some evidence on that phenomenon (Ben-Shahar and Schneider 2010, p. 38). Hence, non-professional investors tend to disregard complex and huge information, which is just a form of transaction costs (Luth and Faure 2011, unpublished). Transaction costs incur in participating in any market transaction (Richter and Furubotn 2010, p. 57). Parts of them are search costs, which include all expenses arising by searching and collecting information while preparing a transaction (Richter and Furubotn 2010, p. 59). Search costs may be distinguished into external and internal costs (Smith et al. 1999, p. 285). While external costs describe measurable monetary costs of acquiring the information needed, internal costs include the whole range of cognitive efforts of the individual market participant concerning searching and sorting of information and integrating with the information already available (Hauser 1993, p. 452; Smith et al. 1999, p. 285; Stigler 1961, p. 213).

Thus, there is no denying the fact that by offering a wider and more complex information basis it leads to a steady increase of (internal) transaction costs for the market participant. This is a consequence of information asymmetries in the operating markets. For these reasons, complex legal wording is seldom understood which is a fact proven by empirical studies (Ben-Shahar and Schneider 2010). Thus, a controlled experiment on the consumers' reactions to the disclosure of a broker's compensation evidenced a significant confusion of the consumers hereby (Lacko and Pappalardo 2004). In detail, the result of the study was that the disclosure of brokers' provisions caused a significant proportion to choose loans that are more expensive than the available alternatives, and created a substantial consumer bias against broker loans, even when the broker loans cost the same or less than direct lender loans (Lacko and Pappalardo 2004). Moreover, recent research indicates that markets suffering from information asymmetry not always are likely to break down, in particular if bounded rational buyers act on markets, which are not being characterized by a high probability of quality assessment risks (Kirstein and Kirstein 2006).

However, this kind of information overload can be counterbalanced by individual consultation and advice (Ben-Shahar and Schneider 2010) as well as by filtering information and condensing it into quality signals by intermediaries - as shown above. Nevertheless, if provided information is more determined to be given to professionals who should then act as some kind of interface to the (consumer-) investor, efficient market mechanisms and sanctions are needed for the intermediaries, thus giving enough incentives to filter and condense information in a proper way. However, as we will discuss later, even professionals suffer from irrational behaviour thus making it more difficult to counterbalance information overload of consumers by means of individual consultation.

With regard to product complexity, the findings of behavioural economics are ambiguous up to now. As Zizzo/Sitzia have shown (Sitzia and Zizzo 2009), complexity of a product does not necessarily lead to an aversion against complex products. On the other side, inability to assess benefits (and risks) of complex products obviously caused negative reactions of consumers in some branches, like in telecommunication tariffs, thus leading to a new form of tariffs like flat rates for phone calls, which are easier to understand. This phenomenon can obviously not be observed in financial markets-and it still seems unclear what all the differences between those markets and learning effects of market participants are about, e.g., whether investors rely more upon personal confidence (provided by the banking agent consulting them), thus, making it more probable that they buy complex financial products even if they do not understand them-which is not the 
fact concerning telecommunication rates - or if repeated games and thus learning effects are responsible for these differences.

Another side of the complexity coin is the reluctance of people to do complex choices, also concerning financial products (Dhar 1997 p. 215), e.g., being offered more than 50 products instead of just 6 products lead people to abstain from buying as they fear to regret their choice afterwards ("choice overload") (de Meza et al. 2008, p. 39). Hence, it is very likely that intermediaries tend to "reduce" artificially or to hide the (real) complexity of financial products in order to avoid the reluctance of consumers to buy them.

\section{Endowment Effects}

Endowment effects signify that due to loss aversion people value what they own more than what they don't own in the sense that they demand more money to give up an object than they would be prepared to pay to acquire it (Kahneman et al. 1991, p. 93; Kahneman et al. 1990, p. 1325). Individuals tend to weigh losses about twice as much as gains (Tversky and Kahneman 1992, p. 297; Kahneman and Tversky 1979, p. 263). In general, the endowment effect reflects a tendency of people to stick to their actual strategies and behaviour and their unwillingness to change them (Samuelson and Zeckhauser 1988, p. 7). This general effect was studied intensively with regard to decisions about pension fund plans (Madrian and Shea 2001, p. 1149; Choi et al. 2006, p. 304).

It is very likely-however, probably not yet been proved in an experiment - that investors and perhaps also professional intermediaries suffer from these effects. Hence, investors cling to their investments in their portfolio even when it would be from a neutral perspective wise to sell stock. Thus, endowment effects are more relevant for consultation obligations concerning management of assets rather than before buying stock and securities.

The endowment effect may even be forced by another behaviour observed during the process of taking an investment decision-the reflection effect. It describes a phenomenon of mental accounting. People tend to be significantly affected by framing an investment opportunity. They subjectively frame a transaction in their mind, which will determine the utility they receive or expect (Klöhn 2005, p. 95; Tversky and Kahneman 1986, p. 251; Tversky and Kahneman 1981, p. 453). Closely connected to these effects is the so-called status quo bias; here, investors tend not to change an established behaviour unless the incentive to change is compelling (Klöhn 2005, p. 97; Samuelson and Zeckhauser 1988, p. 7).

\section{Procrastination}

Procrastination refers to the delay of taking an action in spite of being aware that prompt action would be better. Cognitive psychologists claim that present or immediate costs/benefits are unduly salient or vivid in comparison to future costs/benefits. In contrast to rational behaviour assumption benefits and costs incurred in the future are weighed much more less than those today ("hyperbolic discounting utility") (Phelps and Pollak 1986, p. 201) due to the fact that people are preferring more comfort activities or to avoid emotional distress. This effect in particular affects financial planning and investment strategies as people are inclined to cling - together with the endowment effect - to their existing portfolio rather than to sell stock (O’Donoghue and Rabin 2001, p. 121; O’Donoghue and Rabin 1999, p. 103). Following some experiments, simplification may avoid procrastination to some extent (Madrian and Shea 2001, p. 1149). Moreover, adequate default rules will help investors as they are not obliged to take actions rather than stick to "take it as it comes" (Choi et al. 2003, p. 180; de Meza et al. 2008, p. 30). 
Professionals

However, even professional intermediaries and actors on securities markets are affected by irrational effects:

\section{Complex Risk Assessment}

One of the key factors in the financial crisis has been the inability of professional intermediaries to realize the systemic risks that resulted of the asset-backed derivatives and certificates which were issued and sold (Heun 2010, pp. 53, 56). Moreover, long-term implications had been underestimated, short-term orientation prevailed (Hellwig 2010, p. E 39), and led combined with the herding effect to a complete ignorance by professional intermediaries of upcoming financial crisis. Also, the complexity of financial products such as derivatives based themselves on indexes of other derivates obviously added to the already existing failures of how to assess risks (Hellwig 2010, p. E 45).

\section{Overconfidence}

Another phenomenon that could be observed during the crisis was over self-confidence. Managers in banks and financial intermediaries were confident in their own assessment of risks, even if they did not entirely understand the design of the financial products. However, also (and perhaps more) private investors suffer from overconfidence (Barber and Odean 2001, p. 261). This phenomenon has been proved in several experimental studies and comes along with the phenomenon of over optimism and wishful thinking (Irwin 1953, p. 329; Klöhn 2005, p. 116; Kunda 1987, p. 636; Weinstein 1980, p. 806). The effect of over self-confidence especially refers to the aspects of precision of the own knowledge (Alpert and Raiffa 1982, p. 294; Einhorn and Hogarth 1978, p. 395; Lichtenstein and Fischhoff 1977, p. 159), the own skills and expertise (Frank 1935, p. 285) and generally unrealistic positive self-perceptions (Greenwald 1980, p. 603).

Differing from over self-confidence another factor contributes to the sum of failures: the overconfidence in the rating and assessment by rating agencies. Bankers relied heavily upon the assessment of new financial products not realizing that rating agencies themselves had no experience in these markets of house loans and derivative products (Hellwig 2010, p. E 20).

\section{Herding}

One more famous effect that could be distilled out of numerous behavioural economics experiments affected deeply professional intermediaries in the financial sector: herding (Banerjee 1992, p. 797; Graham 1999, p. 237; Micklitz 2010; Nofsinger and Sias 1999, p. 2263; Scharfstein and Stein 1990, p. 465; Shiller 2000, pp. 149-153; Welch 2000, p. 369). As people tend to follow the "main stream" which is being represented by a peer group or a peer leader they ignore signs and indicators that given a rational behaviour would lead them to different assessments of the actual situation and would likely cause different actions. There is a natural tendency of individuals to simplify complex decision taking processes which leads them to just copy decisions of others. Hereby, the individual develops a certain security with the chosen path, since others decided the same way (conformity effect) (Asch 1956; Klöhn 2005, p. 124).

Thus, herding is a typical phenomenon of distorted rational behaviour, which is being incurred by everyone, also professionals. Nevertheless, herding can-especially with regard 
to professionals - also be explained by rational aspects: such as common predispositions (education, experiences, methods) of agents, which lead them to receive the same information to interpret it in the same way and to conclude comparable investment decisions (Froot et al. 1992, p. 1461; Klöhn, 2005, p. 125). Furthermore, there is a strong influence of principal-agency aspects as long as bankers are paid and compared in relation to their reference peer group members. Here is a strong incentive not to differ from mainstream decisions (Klöhn 2005, p. 125; Scharfstein and Stein 1990, p. 465).

For these reasons, in the financial crisis numerous bankers just hopped on the main stream of investing more and more in structured financial products as all other had been doing before, in order not to miss promising benefits in the future and in order to justify themselves face to (ignorant) shareholders asking them why they had not followed the general trend. Hence, herding affects also the protection of private investors as professional intermediaries consulting these investors suffer from the same herding effects as all professional market participants.

\section{Irrational Effects Reinforced by Revenue Systems}

The short-term orientation of professionals that already could be observed was propelled still by revenue systems used by financial intermediaries as bonus payments and profit sharing was based on a short-term index (Hellwig 2010, p. E 39). Payment systems did not provide for any sharing of losses rather than gains, thus leading to incentives to incur risks on a short-term basis, which were not being balanced against possible losses. Furthermore, there should be noticed a dysfunction of intern controlling systems. It is obvious that there were no strong incentives-even regarding the higher management level - to intensify intern controlling procedures as long as investment departments were distributed considerable profits (Hellwig 2010, p. E 40). However, these factors cannot be assigned to irrational behaviour as they were part of dysfunction of the system. On the contrary, it was perfect rational for professional investors to pursue short-term goals if the whole revenue system was biased on these short-term incentives; hence, it is not due to traditional approaches of rationality in legal provisions rather than to still existing pitfalls of supervising regulations on risk management and revenue policies.

With regard to selling financial products to private investors most banking agents and financial intermediaries were bound internally by similar incentive schemes because they received commission fees when selling specific financial products to their clients - thus undermining their principal obligation to consult the client in a proper and (mostly) neutral way ("kick-back-systems") (Burlingame and Jackson 2007, p. 289).

\section{Normative Implications}

Given all these (and much more) (Ben-Shahar and Schneider 2010, p. 48), distortions of rational behaviour and looking at the fact that the assumption of rational behaviour underpins in general legal regulations of financial markets it is quite arguable whether the traditional legal approach to investor protection is still adequate. However, before turning to specific implications for legislators, we have to take a closer look at a fundamental issue regarding normative impacts of behavioural economics.

It is important to note that the behavioural economic approach never pretended to formulate normative principles - in contrast to neo-classical economics (and neo-institutional economics) 
which could be used either for empirical testing as economic models served as a base for empirical verification or for normative use giving "user" a guideline to an ideal efficient market economy, also identifying the gaps and pitfalls of market mechanisms which should be regulated by legal institutions (Salzberger 2008, pp. 23, 29). The traditional efficiency model was (and is) able to identify first best, second best, etc. solutions for given problems thus enabling legislators (as well as courts etc.) to use efficiency criteria as a means solving legal problems (Eidenmüller 1995, pp. 397, 414; Fleischer and Zimmer 2008, p. 9; Fuchs, 2008, p. 69; Köndgen 2008, p. 100; Kübler 2008, p. 90; Posner 2007, pp. 529, 555; Schäfer and Ott 2000, pp. 1, 452). Especially legal terms like good faith, common usage, etc., which require a judgmental interpretation and are not defined by the law itself, offer a wide scope of application of economic analysis (Eidenmüller 1995, p. 401).

In contrast, behavioural economics concentrates upon empirical testing of behavioural assumptions in a given framework - thus forming the only way to verify neo-classical/ institutional economic arguments besides econometric statistical testing. However, it is quite arguable whether these findings can always be generalized - what is a crucial requirement for legislators. In other words, the results of behavioural experiments may be restricted to certain framework conditions, in particular to a cultural background of tested people or their actual circumstances in living (Arlen 1998, p. 1765; Posner 1998, p. 1551). Hence, it is not surprising that behavioural finance is being criticised for cherry picking and not developing a general theoretical framework (Fama 1998, p. 283).

Moreover, knowing the limits of assumptions about rational behaviour says nothing about how to overcome irrationalities, how to correct inefficient market processes which are due to irrational behaviour (Eidenmüller 2005, pp. 216, 223). Insofar, the classical "rational" assumption as substructure for legislative actions might constitute a more usable solution as long as harmful, deleterious decisions can be avoided (Eidenmüller 2005, pp. 216, 223). Behavioural economics (finance) is (and will be) still lacking the normative side of the coin - and it is not intended to deliver a new normative background of the traditional normative efficiency criteria.

Hence, most lawyers still cling to the vision of rational behaviour as they stress the normative philosophy of legal rules. They uphold still the belief that legislators should not just describe reality but establish normative rules in order to seek contract parity between contracting parties (Buchner and Rehberg 2007, pp. 397, 401; de Meza et al. 2008; Vogt 2010, pp. 741, 753).

Should we then just notice that there are irrational distortions of the traditional efficiency approach and just go on by sticking to the traditional approaches? The answer in the light of financial crisis is clearly negative - even without a normative flip of the efficiency coin we have to modify traditional approaches in order to take possible distortions into account. The story is no different from the upcoming of neo-institutional economics with the pathbreaking articles of Coase upon the impact of transaction costs (Coase 1960, p. 1). Whereas neo-classical economics never cared about transaction costs on markets and never inserted in their formulas likewise factors, neo-institutional economics introduced these new kinds of "distortions" to market mechanisms, thus explaining legal institutions as well as firms as alternative organizational forms to markets (Coase 1937, p. 386). Hence, the impact of behavioural economics on using efficiency criteria can be seen in a similar way, modifying traditional assumptions of the model, however not leading to a radical waiver of the normative criteria of efficiency. In other words, behavioural economics just makes the models more complex - and legislation also-but it does not change the given approach fundamentally. And moreover, the findings of behavioural economics themselves have to be tested thoroughly as it is still an unresolved issue whether the 
behavioural evidence really reflects a fundamental market failure of (USA) securities markets (Bainbridge 2000, pp. 1023, 1054). However, given the fact that the results of behavioural economics do in part undermine or modify components of the classical economic analysis like the homo oeconomicus and the Coase Theorem, and further considering that the economic analysis which is based on those principles has become an important factor in legal sciences (Eidenmüller 2005, pp. 216, 224; Eidenmüller 1995, p. 400; Mülbert and Steup 2005, pp. 1633, 1640; Posner 2007, p. 23) behavioural sciences might lead to a reconsideration of traditional solutions and to a turning to at first sight radical options, like a strong paternalism.

\section{Reform/Enhancement of Investor Protection (in the Light of Behavioural Economics)}

Given all the kinds of anomalies the crucial issue for legislators is whether there is any chance to cope with them, and if so, how:

A pure market-based solution without any regulation clearly has failed; long-term effects (learning effects) and new evolving markets (reputation markets) cannot be waited upon in securities markets as they are faced with systemic risks and might collapse due to shortterm effects. Even if the performance of intermediaries should be enhanced in future, the fundamental problem of irrational behaviour is not yet being coped with; better signaling just makes it easier to endorse complex information in an investment decision but it does not eliminate or overcome all effects of irrational behaviour. Herding, endowment effects or over self-confidence are still lingering on.

\section{Strong Paternalism?}

If traditional approaches based on rational behaviour and on more information for investors are not working out, is the solution then a radical one, replacing market mechanisms by a form of state paternalism? Such paternalism could consist in a strong state control of innovative financial products which might be introduced in order to overcome information overload and asymmetry problems (Luth and Faure 2011, unpublished), thus replacing more or less rating agencies and private signalling mechanisms. With regard to controls of emission prospectus, which could serve as a blueprint every new financial product such as structured financial certificates could need a specific authorization. Without going more into details this would be, however, a bad trade off as state agencies themselves suffer from severe problems as a huge overload of work and inadequate man power as well as being captured by interests, etc. It is no wonder that financial supervising agencies such as the German Financial Market Supervision Agency refuse to control the real content of a prospectus issued for an initial public offering up to now (Küting 2006, pp. 1007-1008; Leuering 2008, § 13 recital 21; Schlitt and Schäfer 2005, pp. 498, 506; Weber 2004, pp. 360, 365). ${ }^{16}$ There is no guarantee that a regulator should know the efficient equilibrium better than an even distorted market (Bainbridge 2000, pp. 1023, 1056). Hence, it is very probable that a totally public controlled market may lead to inefficiencies than markets, which suffer from irrational behaviour. Thus new innovative products might be blocked or at least being delayed for a long time. A slight and careful extension of rating agency activities

${ }^{16}$ Official BaFin statement, downloadable at: http://www.bafin.de/nn_723254/DE/Verbraucher/Prospekte/ prospekte_node.html?_nnn=true (accessed 27 April 2011). 
as well as their intense regulation (and supervision) might serve, however, as a better solution, moreover, if conflicts of interests are being avoided by strict separation of consulting and certification activities. The evolution of regulations on auditors' activities may serve as a blueprint for the discussion, ${ }^{17}$ as well as regulations of certifiers for product safety etc. ${ }^{18}$

\section{Contractual, Liability, and Procedural Means to Cope with Irrational Behaviour}

Still, however, these regulations would change nothing concerning irrational behaviour of market participants; they just aim at reducing informational asymmetries by regulating secondary markets which serve as reputational markets or markets for quality signalling. Coping with herding, endowment etc. might be difficult, as legislators cannot replace individuals making decisions (sceptical also Micklitz 2010, recital 127). Means to cope with these effects may be found in better withdrawal rights and rights of termination going beyond already existing possibilities for clients/investors to cancel a contract ${ }^{19}$ - however, these rights are normally not suitable for securities markets as causality problems will arise, in other word: it will be difficult to distinguish between windfall profits for an investor (just due to market evolutions) and real damages occurred to irrational behaviour. Hence, in summary, scepticism persists regarding the chances for legislator to cope with irrational behaviour. Nevertheless, improvements and enhancements of existing rights, in particular coping with civil procedural problems for investors (such as evidence for causality) may be a little, but significant step towards coping with irrational behaviour. One of the main problems for private investor refers to their difficult situation to prove at court improper consultation and information as well as calculating damages. ${ }^{20}$ Whereas, these problems are also not directly related to irrational behaviour an improvement of the situation for investors with regard to their burden of proof may lead to a higher probability of indemnification for investors, thus creating incentives for banks and intermediaries to avoid situations which might cause irrational behaviour of clients - and to improve consultation etc. in order to overcome informational asymmetries. Thus, a general shift of burden of proof, which goes beyond existing tools to help customers of financial intermediaries, may lead to a more careful consultation as well as documentation of investment decisions. It should be then up to the bank to prove that the investor would have decided either way even if he would have been properly informed.

\footnotetext{
${ }^{17}$ Due to a growing number of scandals regarding balance sheets in the EU and the USA, the European Council and the European Parliament had developed some new regulations on the directive on auditor's activities. The aim was to guarantee a larger scope of independence of the auditors in order to regain investors' trust. The newly developed directive on auditor's activities (Directive 2006/43/EG, 09.6.2006) of the European Council from 2006 merges the earlier three directives 84/253, 83/349, 78/660. It is to ensure more transparency and independence of the auditors, who have to be named in an electronic register. Before working for a company, a proof of independence from the directors of the company must be given. The directive also constitutes fixed specific standards for auditors' activities to guarantee the quality of the auditors' work.

${ }^{18}$ Official guideline for audits of quality and environmental management systems DIN EN ISO 19011:2002.

${ }^{19}$ See the recommendations of the OECD consumer policy toolkit, summaries downloadable at: http://www. oecd.org/document/34/0,3343,en_2649_34267_44074466_1_1_1_1,00.html\#main (accessed 27 April 2011) also presented by Lissowska, in this volume; see also Mair in this volume on cooling-off periods needed rather than more information.

${ }^{20}$ The problems of civil action are not specific to claims based on financial consultation, see Howells in this volume, with regard to tobacco product liability litigation.
} 
Concerning the "making" of financial products we have argued that a rigid state control of new financial products could be ineffective. However, this does not exclude other means, in particular obligations stemming from private law. If we look at producers' liabilities in other industrial sectors, we note in all jurisdictions more or less an obligation to test the product before it is being introduced and sold in markets. ${ }^{21}$ Concerning financial products such a "test" would imply on one side testing implied systematic risks which are due to the fact of over-complexity of a product that even professionals are not able to understand or to assess its risks. Moreover, this "test" could encompass also instructions given to the potential investor (like instruction manuals in producer`s liability), in particular their level of transparency, clearness and comprehensibility.

\section{Organizational means and Revenue Systems to Counterbalance Irrational Behaviour}

Concerning professional intermediaries, however, it is much more important to counterbalance the effects of anomalies such as herding. Whereas it is also difficult to avoid irrational behaviour by legal regulations these may serve as incentives for the organizations/financial firms to introduce better systems to check against irrational behaviour. In other words, there is no way for a legal system simply to "forbid" irrational behaviour, which is simply there and existing and cannot be "ruled away." Crucial is therefore to introduce counterbalancing measures such as organizations which take into account and mitigate the deficits resulting of irrational behaviour. This might be seen as an extension of existing risk managements - which, however, currently are not sufficient to cope with irrational anomalies in their organizations (Heun 2010, pp. 53, 56; Spindler 2010, pp. 601-602).

A more radical approach would be to oblige banks to consult only on basis of a feebased contract, thus avoiding the conflict of interests that mostly arises out of necessities of distribution - and which emphasizes already existing incentives to exploit irrational behaviour (and trust) of investors. If banks would be forced to invoice consultation fees, cross-subsidies would be made impossible; transparency in consultation markets could thus lead to the development of independent consultants who suffer today by a market failure due to the fact that clients generally are not willing to pay fees for being informed in an independent way. Like in insider trading law, banks could be obliged to develop at least a Chinese wall between their financial product lines and the bank agents, which consult their customers. Moreover, as the findings of David Leiser has shown, any strict avoidance of conflict of interests is better suited to balance the behavioural anomalies than a mere disclosure of conflict of interests, in particular regarding "kick-back" payments (Leiser 2011, unpublished). Thus, the approach of the MiFID, which allows financial intermediaries

\footnotetext{
${ }^{21}$ The German producers' duties to monitor the construction, the fabrication of goods and to inform clients about all kinds of possible risks as well as to observe the development of the goods and possible defects after the market introduction can be seen as a model obligation, in this regard König, 2003, p. 106; the duty to test new products according to the latest insights of science and technology before being introduced into to the market and to reduce given risks to a minimum is deducted mainly from the duty to properly monitor the construction, Mertens 2009, $\S 823$ recital 283; Spindler 2008, $\S 823$ recital 494; Federal Court of Justice (BGH) (2009), judgement of 16.12.2008-ref. no. VI ZR 170/07, Neue Juristische Wochenschrift, p. 1080 (information duty, risk reducing); Federal Court of Justice (BGH) (1989), judgement of 17.10.1989—ref. no. VI ZR 258/88, Zeitschrift für Wirtschaftsrecht, p. 516; Federal Court of Justice (BGH) (1970), judgement of 28.09.1970 - ref. no. VIII ZR 166/68, Wertpapiermitteilungen, p. 1418; Higher Regional Court (OLG) Frankfurt (1993), judgement of 02.02.1993 - ref. no. 22 U 212/91, Neue Juristische WochenschriftRechtsprechungsreport, p. 346 (changed product without warning).
} 
just to disclose their conflict of interest instead of avoiding them completely (Art. 18 MiFID), is led ad absurdum.

Last but not least, existing legal regulations for a long time have introduced the obligation of banks to know their customer. Hence, each investment consultation should in theory start with a thorough check of the knowledge bias of the client-what is not being complied with in practice (Kohlert and Oehler 2011, unpublished). Even more, some of the anomalies cited above are showing up again, such as at the first place over self-confidence of clients which are unlikely to blame themselves as ignorant. Moreover, obviously bank agents tend to ask their clients based on their financial status, thus ignoring fundamental economic factors, and not offering equal consultation to each client (Kohlert and Oehler 2011, unpublished). If banks, however, would be obliged to make a short (maybe standardized) test, using psychological insights, which reveal the real knowledge bias and the real risk aversion of clients the know-your-customer principle would be enforced in a much more systematic way-flanked by an obligation to document the outcome of the test (Willis 2009, p. 415; Willis 2008, p. 197). Moreover, the mostly brought forward argument by banks that the client had not revealed his high risk aversion etc. would be put aside as a documented test will serve as the real base for consulting.

These instruments may also serve as a means to fight malicious exploitation of irrational behaviour of clients by banks and financial intermediaries. In particular in the Lehmann Brother's certificate selling cases it is very likely that financial intermediaries had explicitly took advantage of the low experience and knowledge of customers about risk of these certificates (Späth 2010, pp. 451-452). ${ }^{22}$ Once again, documentation combined with a thorough test, which could be standardized by supervising authorities can lead to a stricter enforcement of the know-your-customer principle.

\section{Investor Protection on Court Level: The Lehmann Brothers Case and Behavioural Economics}

Up to now we discussed briefly traditional behavioural assumptions contained in legislations, more precisely: codifications. However, we may find the same approaches in court (case) law. One of the most interesting cases involving many court actions of damaged investors is the Lehmann Brother insolvency: Banks (and other financial intermediaries having sold Lehmann certificates) are now faced with claims filed by their damaged customers based upon improper consultation by bank agents as well as not disclosed kick-back payments of banks to Lehmann Brothers which induced conflicts of interests (Brinckmann 2010, pp. 45 ff.; Fullenkamp 2011, pp. 421 ff.; Langen 2010, pp. 19451946; Nodoushani 2011, pp. 1 ff.; Späth 2010, pp. 451 ff.). ${ }^{23}$ These two main streams of reasoning in the Lehmann cases reflect exactly the traditional legal approach of investor protection: More and properly given information/consultation would have led to right and informed decisions of investors who would have then avoided any investments in Lehmann certificates.

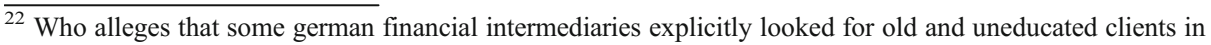
order to sale these certificates.

${ }^{23}$ See also Higher Regional Court (OLG) queryDresden (2010), judegement of 11.05.2010 - ref. no. 5 U 1178/09, Zeitschrift für Wirtschaftsrecht und Insolvenzpraxis, pp. 1230 ff.; Higher Regional Court (OLG) Frankfurt (2010), judgement of 29.12.2010 - ref. no. 19 U 94/10, Der Betrieb, pp. 1119-1120; Higher Regional Court (OLG) Düsseldorf (2010), judgement of 04.10.2010 - ref. no. I-9 13/10, 9 U 13/10.
} 
The legal reasoning of most decisions was based on negligent behaviour of the bank consultants. For instance, one bank was sentenced to damages due to missing disclosure of conflict of interests, in particular internal kick-back-payments, and missing indications of non-existing guarantees. ${ }^{24}$ However, the decision has been overruled by the Higher Regional Court of Hamburg, which denied a contract violation through the consultation regarding Lehmann certificates (Späth 2010, p. 451). Other legal arguments refer to imprecise information about the emitter, to provisions (as the aforementioned kick-back), solvency risks and down ratings or even a missing indication of negative articles about the Lehmann Company in the media (Späth 2010, p. 451). Some requests for damages have not been settled at court but rather at the Ombudsman of private banks according to the same legal arguments. ${ }^{25}$

Thus, the court decisions reflect the same traditional approaches to behaviour of investors as legislations as courts rely upon sufficient information and disclosure of conflict of interests in order to enable the investor to make up his mind according to a sufficient basis of information. However, as the short tour across results of behavioural economics research has shown, doubts are nourished whether these assumptions are still valid. Would investors really have refrained from investing in Lehmann certificates if they would have received more and correct information such as the missing guarantee by national funds? Would they really have denied any investment in Lehmann certificates once they were informed about "kick-back" payments by banks to Lehmann?

As David Leiser has shown, a disclosure of kick-back payments may have even contradictory outcomes such as more confidence being attributed by people who have no qualified education than before disclosure. Things are getting worse in cases of face-to-face communication as people believe in their counterpart, ignoring disclosed facts. Moreover, Leiser lays accent on the fact that people with lower educational level do not know how to discount information from a source with conflict of interest and do not know where to turn to in order to get "neutral" information. Hence, disclosure is not the best solution rather than total avoidance of conflict of interests-which is under actual legal regulations in Europe not the case, banks may act as well as consultants as "producers" of new financial products.

\section{Outlook}

The tour d'horizon of the use of assumptions about rationale behaviour in legal investor protection rules has shown a wide reliance upon market mechanisms and the ability of investors to understand and use information. However, behavioural economics has demonstrated that we will have to reassess in a wide range these traditional assumptions; hence, we have to redefine and readjust our legal fundaments to the new insights of how people really behave. Nevertheless, it would be early to argue for a radical shift in paradigms from a market-orientated approach to a state-regulatory, paternalistic approach. In particular, the still missing coherent theory of behavioural finance and its lacking

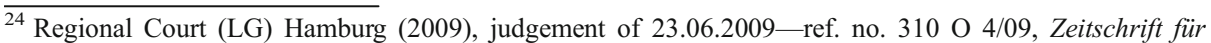
Wirtschaftsrecht, p. 1311; the same reasoning in Regional Court (LG) Hamburg (2009), judgement of 10.07.2009-ref. no. 329 O 44/09 (Commerzbank), Wertpapiermitteilungen, p. 1511.

${ }^{25}$ A report of the Ombudsman's activities in 2009 can be found at: https:/www.bankenverband.de/themen/ politik-gesellschaft/infodienst-interesse/08-2010/ombudsmann-der-privaten-banken-auch-in-zeiten-derfinanzkrise-bewaehrt/?searchterm=lehman (accessed 27 April 2011).
} 
normative side renders the task for legislators even more complicated. Thus, a step-by-step approach taking into account specific behavioural deviations would be likely to be more adequate than a total paternalistic approach.

Open Access This article is distributed under the terms of the Creative Commons Attribution Noncommercial License which permits any noncommercial use, distribution, and reproduction in any medium, provided the original author(s) and source are credited.

\section{References}

Akerlof, G. A. (1970). The market for "lemons": Quality uncertainty and the market mechanism. Quarterly Journal of Economics, 84(3), 488-500.

Alpert, M., \& Raiffa, H. (1982). A progress report on the trainng of proability assecors. In D. Kahneman, P. Slovic, \& A. Tversky (Eds.), Judgement under uncertainty: Heuristic and biases (pp. 294-305). Cambridge: Cambridge University Press.

Arlen, J. (1998). The future of behavioural economic analysis of law. Vanderbilt Law Rev, 51, 1765-1788.

Asch, S. (1956). Studies of independence and conformity: A minority of one against a unanimous majority. Psychological Monographs, 70(9), 416.

Bainbridge, S. (2000). Mandatory disclosure: A behavioural analysis. University of Cinicinnati Law Review, $68,1023-1060$.

Banerjee, A. (1992). A simple model of herd behaviour. Quarterly Journal of Economics, 107(3), $797-817$.

Barber, B., \& Odean, T. (2001). Boys will be boys: Gender, overconfidence, and common stock investment. Quarterly Journal of Economics, 116, 261-292.

Ben-Shahar, O., \& Schneider, C. (2010). The failure of mandated disclosure. U. of Chicago Law \& Economics Olin Working Paper No. 516 and U. of Michigan Law \& Economics, Emperical Legal Studies Center Paper No. 10-008. Available at http://papers.ssrn.com/sol3/papers.cfm?abstract_id=1567284. Accessed 27 April 2011.

Bollerslev, T., Engle, R. F., \& Wooldridge, J. M. (1988). A capital asset pricing model with time-varying covariances. The Journal of Political Economy, 96(1), 116-131.

Brinckmann, H. (2010). Lehman-Zertifikate und die Neuregelungen bei der Anlageberatung anlässlich der Reform des SchVG_-Lässt sich eine vorsichtigere Beratungspraxis etablieren? Zeitschrift für Bank- und Kapitalmarktrecht, 10, 45-52.

Buchner, B., \& Rehberg, M. (2007). Wann ist der Verbraucher ein “mündiger" Verbraucher? Zur Diskussion um die Nutrition \& Health Claims-Verordnung der EU. Gewerblicher Rechtsschutz und Urheberrecht International, 56, 394-491.

Burlingame, L., \& Jackson, H. (2007). Kickbacks or compensation: The case of yield spread premiums. The Stanford Journal of Law, Business \& Finance, 12(2), 289-361.

Camerer, C. (1995). Individual Decision Making. In J. H. Kagel \& A. E. Roth (Eds.), The handbook of experimental economics (pp. 587-703). Princeton: Princeton University Press.

Camerer, C., Loewenstein, G., \& Weber, M. (1989). The curse of knowledge in economic settings: An experimental analysis. The Journal of Political Economy, 97(5), 1232-1254.

Camerer, C., Isacharoff, S., Loewenstein, G., O’Donoghue, T., \& Rabin, M. (2003). Regulation for conservatives: Behavioral economics and the case for asymmetric paternalism. University of Pennsylvania Law Review, 151, 1211-1254.

Cherednychenko, O. O. (2010). The Regulation of retail investment services in the EU: Towards the improvement of investor rights? Journal of Consumer Policy, 33(4), 403-424.

Choi, J., Laibson, D., Madrian, B. C., \& Metrich, A. (2003). Optimal defaults. The American Economic Review, 93(2), 180-185.

Choi, J., Laibson, D., Madrian, B. C., \& Metrich, A. (2006). Saving for retirement on the path of least resistance. In: E. McCaffrey \& J. Slemrod (Eds.), Behavioural Public Finance (pp. 304-351). Available at: http://works.bepress.com/edward_mccaffery/15. Accessed 27 April 2011.

Clouth, P., \& Lang, V. (2007). MiFID-Praktikerhandbuch. Koeln: Bank-Verlag. 
Coase, R. H. (1937). The nature of the firm. Economica, 4(16), 386-405.

Coase, R. H. (1960). The problem of social cost. Journal of Law and Economics, 3, 1-44.

Covitz, D., \& Harrison, P. (2003). Testing conflicts of interest at bond ratings agencies with market anticipation: Evidence that reputation incentives dominate. FEDS Working Paper No. 2003-68. Available at: http://papers.ssrn.com/sol3/papers.cfm?abstract_id=512402. Accessed 27 April 2011.

de Meza, D., Irlenbusch, B., \& Reyniers, D. (2008). Financial capability: A behavioural economics perspective. Available at: http://www.fsa.gov.uk/pubs/consumer-research/crpr69.pdf. Accessed 27 April 2011.

Dhar, R. (1997). Consumer preference for a no-choice option. Journal of Consumer Research, 24(2), $215-231$.

Duve, C., \& Keller, M. (2006). MiFID: Die neue Welt des Wertpapiergeschäfts. Betriebs-Berater, 61, $2425-2432$.

Eidenmüller, H. (1995). Effizienz als Rechtsprinzip. Tuebingen: Mohr Siebeck.

Eidenmüller, H. (2005). Der homo oeconomicus und das Schuldrecht: Herausforderungen durch Behavioural Law Economics. Juristenzeitung, 60, 216-224.

Einhorn, H., \& Hogarth, J. (1978). Confidence in judgement: Persistance of the illusion of validity. Psychological Review, 85(5), 395-416.

Ellenberger, J., \& Schaefer, F. A. (2006). Fehlgeschlagene Wertpapieranlagen. Heidelberg: Finanz Kolloquium.

Fama, E. F. (1970). Efficient capital markets: A review of theory and empirical work. The Journal of Finance, 25(2), 383-417.

Fama, E. F. (1998). Market efficiency, long-term returns, and behavioural finance. Journal of Financial Economics, 49, 283-306.

Fama, E. F., \& French, K. R. (2004). The capital asset pricing model: Theory and evidence. Journal of Economic Perspectives, 18(3), 25-46.

Fleischer, D., \& Zimmer, H. (2008). Effizienzorientierung im Handels- und Wirtschaftsrecht- Einführung und Überblick. Zeitschrift für das gesamte Handels- und Wirtschaftsrecht Beiheft, 74, 9-42.

Frank, J. (1935). Some psychological determinants of the level of aspiration. The American Journal of Psychology, 47(2), 285-293.

Froot, K. A., Scharfstein, D. S., \& Stein, D. C. (1992). Herd on the street: Informational inefficiencies in a markt with short-term speculation. The Journal of Finance, 47(4), 1461-1484.

Fuchs, F. (2008). Effizienzorientierung im Wettbewerbs- und Kartellrecht? Zeitschrift für das gesamte Handels- und Wirtschaftsrecht Beiheft, 74, 69-89.

Fullenkamp, J. (2011). Kick-Back-Haftung ohne Ende? Neue Juristische Wochenschrift, 64, 421-426.

Galagedera, D. U. A. (2004). A review of capital asset pricing models. Victoria: Monash University.

Geanakoplos, J., \& Shubik, M. (1990). The capital asset pricing model as a general equilibrium with incomplete markets. The Geneva Papers on Risk and Insurance Theory, 15(1), 55-71.

Gilson, R. J., \& Kraakman, R. H. (1984). The mechanisms of market efficiency. Virginia Law Review, 70, 549-644.

Goodhart, C. A. E. (2008). The background to the 2007 financial crisis. International Economics and Economic Policy, 4(4), 331-346.

Graham, J. (1999). Herding among investment newsletters: Theory and evidence. The Journal of Finance, 54 (1), 237-268.

Greenwald, A. (1980). The totalitarian ego-fabrication and revision of personal history. Amercian Psychologist, 35(7), 603-618.

Grundmann, S. (2005). European Review of Contract Law (ERCL), p. 482.

Grundmann, S. (2008). European Review of Contract Law (ERCL), p. 45.

Grundmann, S. (2010). European Review of Contract Law (ERCL), p. 467.

Grüneberg C., Sutschet H. (2007). § 311 Abs.2 Begründung vorvertraglicher Pflichten. In Bamberger H. G., Roth H. (Eds.), Kommentar zum Bürgerlichen Gesetzbuch (BGB) 1 (2nd. ed.) (pp.1399-1414). Munich: Beck Juristischer Verlag.

Hannöver (2007). § 110 Beratungs- und Informationspflichten im Effektengeschäft. In H. Schimansky, H. J. Bunte, \& H. J. Lwowski (Eds.), Bankrechts-Handbuch II (3rd ed.) (pp.1149-1172). Munich: Beck Juristischer Verlag.

Hauser, J. (1993). How consumers allocate their time when searching fo information. Journal of Marketing Research, 30(4), 452-466.

Hellwig, M. (2010). Finanzmarktregulierung-Welche Regelungen empfehlen sich für den deutschen und europäischen Finanzsektor-Finanzkrise und Reformbedarf. In M. Hellwig, W. Hoefling, \& D. Zimmer (Eds.), Finanzmarktregulierung - Welche Regelungen empfehlen sich für den deutschen und europäischen Finanzsektor? Gutachten E/F/G zum 68. Deutschen Juristentag (pp. E 9-E 57). Munich: Verlag C. H. Beck.

Heun, W. (2010). Der Staat und die Finanzkrise. Juristenzeitung, 65, 53-62.

Hirshleifer, D. (2001). Investor psychology and asset pricing. Journal of Finance, 56(4), 1533-1597. 
Hopt, K. (2009). 50 Jahre Anlegerschutz und Kapitalmarktrecht: Ein Rückblick und Ausblick. Wertpapiermitteilungen, 63, 1873-1881.

Irwin, F. (1953). Stated expectations as functions of probability and desirability of outcomes. Journal of Personality, 21(3), 329-335.

Jensen, M. C. (1978). Some anomalous evidence regarding market efficiency. Journal of Financial Economics, 6(2/3), 95-101.

Kahneman, D., \& Tversky, A. (1979). Prospect theory: An analysis of decision under risk. Econometrica, 47 (2), 263-292.

Kahneman, D., Knetsch, J. L., \& Thaler, R. H. (1990). Experimental tests of the endowment effect and the Coase theorem. The Journal of Political Economy, 98(6), 1325-1348.

Kahneman, D., Knetsch, J. L., \& Thaler, R. H. (1991). Anomalies: The endowment effect, loss aversion, and status quo bias. The Journal of Economic Perspectives, 5(1), 193-206.

Kirstein, R. \& Kirstein, A. (2006), Europäischer Verbraucherschutz-Ausdruck grenzenloser Regulierungswut oder sinnvoller Schutz für Käufer? Center for the Study of Law and Economics, Discussion Paper 2006-08. Available at: http://econstor.eu/bitstream/10419/23086/1/2006-08 verbraucher-experiment.pdf. Accessed 27 April 2010.

Klöhn, L. (2005). Kapitalmarkt, Spekulation und Behavioral Finance. Berlin: Duncker und Humblot Verlag.

Köndgen, J. (2008). Effizienzorientierung im Kapitalmarktrecht?? Zeitschrift für das gesamte Handels- und Wirtschaftsrecht Beiheft, 74, 101-105.

König, A. (2003). Produktsicherheitsgesestz und Produkthaftung (Doctoral dissertation, Universtität Halle-Wittenberg 2001/2002). Koeln: Heymann Verlag.

Kübler, F. (2008). Effizienzorientierung im Gesellschaftsrecht? Zeitschrift für das gesamte Handels- und Wirtschaftsrecht Beiheft, 74, 90.

Kunda, Z. (1987). Motivated inference: Self-serving generation and evaluation of causal theories. Journal of Personality and Social Psychology, 53(4), 636-647.

Küting, P. (2006). Neufassung des IDW S 4-Auf dem Weg von einer freiwilligen zu einer gesetzlich kodifizierten Prospektprüfung? Deutsches Steuerrecht, 44, 1007-1013.

Lacko, J., \& Pappalardo, J. (2004). The effect of mortgage broker compensation disclosures on consumers and competition: A controlled experiment. Federal Trade Commission Bureau of Economics Staff Report. Available at: http://www.ftc.gov/os/2004/01/030123mortgagefullrpt.pdf. Accessed 28 April 2011.

Lang, V. (2003). Informationspflichten bei Wertpapierdienstleistungen. Rechtliche Grundlagen, typenspezifische Anforderungen, Haftung. Munich: Beck Juristischer Verlag.

Langen, M. (2010). Higher Regional Court (OLG) Hamburg: Keine Aufklärungspflicht der beratenden Bank über ihre Gewinnmargen (Lehman-Brothers). Betriebs-Berater, 65, 1945-1948.

Leuering D. (2008). § 13 Billigung des Prospekts. In Holzborn T. (Ed.), Wertpapierprospektgesetz (pp.745759). Berlin: Schmidt Erich.

Lichtenstein, S., \& Fischhoff, B. (1977). Do those who know more also know more about how much they know? Organizational Behaviour and Human Performance, 20(2), 159-183.

Liu, P., \& Thakor, A. V. (1984). Interest yields, credit ratings, and economic characteristic of State Bonds: An empirical analysis: Note. Journal of Money, Credit and Banking, 16(3), 344-351.

Madrian, B., \& Shea, D. (2001). The power of suggestion: Inertia in 401(k) participation and savings behaviour. Quarterly Journal of Economics, 116(4), 1149-1187.

Markowitz H.M. (1959). Portfolio selection: efficient diversification of investments. New York: Wiley.

Merkt, H. (2010). Kapitalmarktrecht-Ursprünge, Genese, aktuelle Ausprägung, Herausforderungen. In S. Grundmann, B. Haar, H. Merkt, P. O. Mülbert, M. Wellenhofer, H. Baum, et al. (Eds.), Festschrift für Klaus J. Hopt zum 70. Geburtstag am 24. August 2010: Unternehmen, Markt und Verantwortung (pp. 2207-2246). Berlin, New York: De Gruyter.

Mertens (2009). §§ 823-829 Unerlaubte Handlung. In K. Rebmann, F. J. Säcker, R. Rixeker (Eds.), Münchener Kommentar zum Bürgerlichen Gesetzbuch (BGB) 5 (3rd ed.) (pp.1401-1766). Munich: Beck Juristischer Verlag.

Micklitz, H.-W. (2010). Herd and third party impact as a legal concept - On tulips, pyramid games and assetbacked securities. Speech at the Contract Governance Conference in Berlin (10-30-10). Paper soon available at: http://www.the-graphics.de/projects/contractrc1/papers.html. Accessed 27 April 2011.

Moloney, N. (2008). EC Securities regulation (2nd edn.). Oxford: Oxford University Press. Available at: http://www.lnb.lt/stotisFiles/uploadedAttachments/es4200902892512.pdf. Accessed 28 April 2011.

Mülbert, P., \& Steup, S. (2005). Emittentenhaftung für fehlerhafte Kapitalmarktinformation am Beispiel der fehlerhaften Regelpublizität. Wertpapiermitteilungen, 59, 1633-1655.

Neubäumer, R. (2008). Ursache und Wirkung der Finanzmarktkrise-eine ökonomische Analyse. Wirtschaftsdienst, 88, 732-740. 
Nodoushani, M. (2011). Der Einlagensicherungsfond des Bankenverbandes im Lichte der Finanzmarktkrise. Zeitschrift für Bank- und Kapitalmarktrecht, 11, 1-5.

Nofsinger, J., \& Sias, R. (1999). Herding and feedback trading by institutional and individual investors. The Journal of Finance, 54(6), 2263-2295.

O’Donoghue, T., \& Rabin, M. (1999). Doing it now or later. The American Economic Review, 89(1), $103-124$.

O'Donoghue, T., \& Rabin, M. (2001). Choice and procrastination. Quarterly Journal of Economics, 116(1), 121-160.

Phelps, E., \& Pollak, R. (1986). On second-best national saving and game equilibrium growth. The Review of Economic Studies, 35(2), 201-208.

Posner, R. (1998). Rational choice, behavioural economics and the law. Stanford Law Review, 50(5), 1551-1576.

Posner, R. (2007). Economic analysis of law. (7th ed.) New York: Aspen Publishers.

Richter, R., \& Furubotn, E. G. (2010). Neue Institutionenökonomik-Eine Einführung und kritische Würdigung (4th ed.). Tuebingen: Mohr Siebeck.

Salzberger, W. (2008). Law and economics in the $21^{\text {st }}$ century. In O. Eger, C. Ott, J. Bigus, \& G. van Wangenheim (Eds.), Festschrift für Hans-Bernd Schäfer zum 65. Geburtstag (pp. 23-34). Wiesbaden: Gabler Verlag.

Samuelson, W., \& Zeckhauser, R. (1988). Status quo bias in decision making. Journal of Risk and Uncertainty, 1(1), 7-47.

Schäfer, H., \& Ott, C. (2000). Ökonomische Analyse des Zivilrechts (3rd ed.). Berlin: Springer.

Scharfstein, D., \& Stein, J. (1990). Herd behaviour and investment. The American Economic Review, 80(3), $465-479$

Schlitt, M., \& Schäfer, S. (2005). Auswirkungen des Prospektlinie-Umsetzungsgesetzes auf Aktien- und Equity-linked Emissionen. Die Aktiengesellschaft, 50, 498-511.

Schwintowski (2009). § 18 Informationspflichten des Versicherers. In R. M. Beckmann, A. MatuscheBeckmann (Eds.), Versicherungsrechts-Handbuch (2nd. ed.) (pp. 913-953). Munich: Beck Juristischer Verlag.

Seyfried, T. (2006). Die Richtlinie über Märkte für Finanzinstrumente (MiFID)—Neuordnung der Wohlverhaltensregeln. Wertpapiermitteilungen, 60, 1375-1387.

Shiller, R. (2000). Irrational exuberance. Princeton: Princeton University Press.

Sitzia, S., \& Zizzo, D. (2009). Does product complexity matter for competition in experimental retail markets? Theory and Decision, 70, 65-82.

Smith, G., Venkatraman, M. P., \& Dholakia, R. R. (1999). Diagnosing the search cost effect: Waiting time and the moderating impact of prior category knowledge. Journal of Economic Psychology, 20(3), 285-314.

Späth, W. (2010). Lehman-Zertifikate im Fokus der Rechtsprechung der letzten 2 Jahre. Verbraucher und Recht, 25, 451-474.

Spence, M. (1976). Symposium: The economics of information: Informational aspects of market structure: An introduction. Quarterly Journal of Economics, 90(4), 591-597.

Spindler G. (2008). $\S \S 823-853$ Unerlaubte Handlung. In H. G. Bamberger, H. Roth (Eds.), Kommentar zum Bürgerlichen Gesetzbuch (BGB) 2 (2nd. ed.) (pp.1177-1677). Munich: Beck Juristischer Verlag.

Spindler, G. (2009). Aufklärungspflichten eines Finanzdienstleisters über eigene Gewinnmargen?-Ein "KickBack" zu viel. Wertpapiermitteilungen, 63, 1821-1828.

Spindler, G. (2010). Finanzmarktkrise und Wirtschaft. Die Aktiengesellschaft, 55, 601-607.

Spindler, G. \& Tancredi, S. (2011), Die Richtlinie über Alternative Investmentfonds (AIFM-Richtlinie), Wertpapiermitteilungen, (in press).

Steuer, S. (1999). Haftung für fehlerhafte Anlageberatung: Eine unendliche Geschichte. In N. Horn (Ed.), Bankrecht - Schwerpunkt und Perspektiven. Festschrift für Herbert Schimansky (pp. 793-820). Cologne: RWS-Verlag. Komunikationsforum.

Stigler, G. (1961). The economics of information. The Journal of Political Economy, 69(3), 213-225.

Tversky, A., \& Kahneman, D. (1981). The framing of decisions and the psychology of choice. Science, 211 (4481), 453-458.

Tversky, A., \& Kahneman, D. (1986). Rational choice and the framing of decisions. Journal of Business, 59 (4), 251-265.

Tversky, A., \& Kahneman, D. (1992). Advances in prospect theory: Cumulative representation of uncertainty. Journal of Risk and Uncertainty, 5(4), 297-323.

Vogt, S. (2010). Wie viel Information braucht der Durchschnitt? In F. C. Grenzow, B. Grunewald, \& H. Schulte-Nölke (Eds.), Zwischen Vertragsfreiheit und Verbraucherschutz. Festschrift für Friedrich Graf von Westphalen (pp. 741-754). Cologne: Dr. Otto Schmidt Verlag.

Weber, M. (2004). Unterwegs zu einer europäischen Prospektkultur-Vorgaben der neuen Wertpapierprospektrichtlinie vom 4.11.2003. Neue Zeitschrift für Gesellschaftsrecht, 7, 360-366.

Weichert, T., \& Wenninger, T. (2007). Die Neuregelung der Erkundigungs- und Aufklärungspflichten von Wertpapierdienstleistungsunternehmen gem. Art. 19 RiL 2004/39/EG (MiFID) und Finanzmarkt-Richtlinie-Umsetzungsgesetz. Wertpapiermitteilungen, 61, 627-636. 
Weinstein, N. (1980). Unrealistic optimism about future life events. Journal of Personality and Social Psychology, 39(5), 806-820.

Welch, I. (2000). Herding among security analysts. Journal of Financial Economics, 58(3), 369-393.

Willis, L. (2008). Against financial literacy education. Iowa Law Review, 94, 197-285.

Willis, L. (2009). Evidence and ideology in assessing the effectiveness of financial literacy education. San Diego Law Review, 46, 415-458. 